DOI https://doi.org/10.30525/978-9934-26-007-0-18

\title{
ПРОЦЕСУАЛЬНА ФОРМА ТА ЗМІСТ СУДОВОГО РІШЕННЯ В ЦИВІЛЬНОМУ СУДОЧИНСТВІ
}

\author{
Перунова О. М., Леонтьсва Л. В.
}

\section{ВСТУП}

Розгляд цивільної справи зазвичай закінчується винесенням судового рішення, яким вирішується цивільна справа по суті. Судове рішення як ключовий інститут цивільного процесуального права $\epsilon$ найважливішим правозастосовним актом судової влади під час розгляду та вирішення цивільних справ, а також найважливішим видом судових рішень. Багатогранність судового рішення дає змогу розглядати його як постанову суду, яка вирішує цивільну справу по суті, й одночасно як правозахисний акт i як процесуальний документ.

Законодавство визначає зміст судового рішення і як акта правосуддя, $\mathrm{i}$ як процесуального документа, проте такий умовний поділ приводить до непорозуміння. Це різний зміст акта правосуддя i процесуального документа, у якому цей акт виражено.

Звичайно, оформлення цього процесуального акта-документа вимагає знання та застосування певних правил щодо форми та змісту судового рішення.

Г.Г. Фазікош у своїй праці вказує на те, що для судового рішення важлива насамперед законність ${ }^{1}$.

Законність документа означає, що складений процесуальний документ повинен точно відповідати правовим нормам, на основі яких він прийнятий. Процесуальний акт визнається законом, якщо: 1) його прийняття передбачене процесуальним законодавством; 2) він винесений компетентним органом чи особою; 3) постановлений за додержання умов, зазначених у законі; 4) його постановлення відповідає процесуальній формі, позначене послідовністю винесення процесуальних актів ${ }^{2}$.

Методологія складання змісту кожного судового рішення визначається трьома факторами: обставинами розглядуваної цивільної справи, правовими вимогами, висунутими до нього, і процесуальною формою, встановленою законом для актів правосуддя. I якщо фактичні дані у кожній

\footnotetext{
${ }^{1}$ Конституція України від 28 червня 1996 р. Відомості Верховної Ради Украӥни. 1996. № 30. С. 61.

${ }^{2}$ Організація роботи суду : навчальний посібник / I.С. Марочкін, Л.М. Москвіч, О.М. Овчаренко та ін. ; за заг. ред. І.Є. Марочкіна. Харків : Право, 2012. С. 186.
} 
справі індивідуальні та неповторні, то вимоги закону, юридична форма постійні та незмінні.

Цивільне законодавство визначає процесуальну форму і зміст судового рішення, а також вимоги, які висуваються до цього процесуального актадокумента. Додержання процесуальної форми і змісту судового рішення $\epsilon$ однією 3 обов'язкових вимог цивільно-процесуального законодавства, що забезпечує здійснення правосуддя по кожній цивільній справі.

Тому дуже важливо для майбутніх фахівців у сфері права звертати увагу на складання цього процесуального акта-документа. Методика складання судового рішення залежить від багатьох складників. Насамперед це процесуальна форма та зміст судового рішення, юридична техніка викладення цього процесуального документа, технічні способи та прийоми, за допомогою яких викладається цей процесуальний акт-документ.

Складність викладення судового рішення, на нашу думку, полягає в його багатогранності. Суддя повинен під час його складання звертати увагу як застосування законодавства, так і на його оформлення 3 додержанням великої кількості методологічних способів і прийомів. Висновком його викладення повинно бути законне й обгрунтоване судове рішення, яке б задовольнило усіх учасників цивільної справи.

Методологія в узагальненому вигляді - це спосіб пізнання. Методологія вчення про науковий метод пізнання і перетворення; його філософська, теоретична основа; сукупність методів дослідження, що застосовуються в будь-якій науці відповідно до специфіки об’єкта ії пізнання ${ }^{3}$.

Отже, вважаємо, що судове рішення як процесуальний акт-документ залежить від багатьох складників: застосування закону, доказів у справі, наукових підходів дослідження, фіксування цих доказів, їх кінцевого обгрунтування, мотивування висновку судового рішення.

Актуальним залишається питання використання певних методологічних прийомів під час складання судового рішення як процесуального актадокумента.

Процесуальний документ має бути вмотивованим i переконливим. Умотивованість акта - це не тільки наявність у ньому опису діяння, події, обставин, а й посилання на докази, аналіз, відповідні пояснення. Переконливість як самостійна ознака процесуальних рішень завжди пов'язана з їх певним оцінюванням сторонніми особами ${ }^{4}$.

\footnotetext{
${ }^{3}$ Онищук I.I. Техніка юридичного письма в нормативно-правових актах : монографія. Івано-Франківськ : Лабораторія академічних досліджень правового регулювання та юридичної техніки, 2014. С. 64.

${ }^{4}$ Корж А.В. Документація право ділової форми : навчальний посібник : лекції та зразки документів / Ін-т держави і права ім. В.М. Корецького НАН / Нац. акад. внутрішніх справ України. Київ, 2002. С. 187.
} 


\section{1. Процесуальна форма судового рішення}

Цивільне судочинство суворо впорядковане. У ньому кожний суб'єкт виконує зазначені функції, згідно з якими він наділений комплексом прав та обов'язків. Важливу роль у цивільному судочинстві виконує суд, він $є$ обов'язковим суб' єктом цивільних процесуальних правовідносин.

Основним функціональним правом і обов'язком суду $є$ винесення судових рішень. Усяке рішення суду є правозастосовним актом. Постановляючи їх, суди керуються відповідними нормами матеріального i процесуального права. Розглядаючи та вирішуючи кожну цивільну справу, кожне питання, яке виникає у ході розгляду і вирішення справи (а за потреби - і в ході перевірки та виконання), суд застосовує юридичні норми і тим самим втілює свою волю у відповідних рішеннях. Залежно від вирішення питання суд першої інстанції приймає рішення у формі рішень суду, ухвал суду. Так, рішення суду першої інстанції, яким справа вирішується по суті, виноситься у формі рішення. Нарівні із рішенням суд першої інстанції виносить також інші рішення, а саме ухвали (про призначення експертизи, про заміну неналежного відповідача, про забезпечення позову тощо).

Отже, насамперед слід охарактеризувати поняття процесуальної форми i змісту судового рішення, оскільки без цих категорій ми взагалі не матимемо судове рішення як процесуальний акт-документ.

Під час винесення судового рішення підводиться підсумок роботи суду по вирішенню спору сторін. Чіткий і вичерпний аналіз матеріалів усього процесу під час винесення рішення і формулювання висновків суду має здійснюватися у передбаченій законодавством процесуальній формі.

Як зазначає М.А. Гурвіч, судове рішення повинне бути винесене у встановленій законом формі. До вимог форми судового рішення необхідно віднести три моменти: 1) рішення має бути оформлено у вигляді письмового документа; 2) рішення як документ повинне відповідати зазначеному законом змістові та бути викладеним у суворій послідовності; 3) рішення має бути чітким за своїм викладом ${ }^{5}$.

Класифікація щодо засобу виготовлення й оформлення ухвал суду першої інстанції ділить їх на види: ухвали у вигляді окремого процесуального актадокумента, який приєднується до справи, й ухвали, що заносяться до журналу судового засідання. Як окремий процесуальний акт-документ, ухвала суду першої інстанції повинна відповідати вимогам, зазначеним у ст. 209 ЦПК 2019 р. Це питання ми розглянемо далі.

\footnotetext{
${ }^{5}$ Гурвич М.А. Решение советского суда в исковом производстве. Москва : Центр типографии МО СССР им. К.С. Ворошилова, 1955. С. 83-88.
} 
Питання, у якій формі постановляються ухвали судом першої інстанції, залежить від складності вирішуваного питання і від особливостей стадії цивільного процесу, в якій воно виноситься.

Під час винесення ухвал суд повинен дотримуватися принципів змагальності та рівноправності сторін. У судовому засіданні суд має перед винесенням ухвали вислухати усі думки сторін і їхніх представників.

Якщо говорити про сутність рішень суду першої інстанції, то вона $\epsilon$ різною. Так, рішенню суду притаманні такі особливості: воно має індивідуальне значення; це офіційний акт - документ, який виражає волю держави та приймається компетентними органами; воно викликає певні юридичні наслідки індивідуального характеру, $\epsilon$ кінцевою ланкою у певному юридичному складі; є приписом суду на засаді загальних норм індивідуально визначати міру можливої й обов'язкової поведінки для конкретних осіб; $€$ зовнішнім формальним закріпленням результату правозастосування з кожної цивільної справи; воно повинне відповідати закріпленим у цивільному процесуальному законодавстві вимогам.

Сутність ухвал суду першої інстанції полягає в тому, що ухвала $є$ актом правосуддя, котрій притаманна обов'язковість для осіб, щодо яких вона винесена, i для суду (судді), котрий iї постановив (незважаючи на те, що вона може бути оскаржена); на відміну від судового рішення, ухвалі не притаманна така якість, як незмінність; якість виключності притаманна повною мірою лише ухвалам про відмову у визнанні позову i про припинення провадження у справі; ухвалі не притаманна якість преюдиційності; у разі, коли в ухвалі містяться приписи, що вимагають примусової реалізації, законодавець наділяє його якістю виконання.

Рішення й ухвали суду першої інстанції мають певну процесуальну форму i зміст, які є визначеними у законі та від яких залежить значення того чи іншого процесуального акта-документа у структурі цивільно-процесуальної форми.

Значення судового рішення, на нашу думку, зумовлене завданням цивільного судочинства, котрим є справедливий, неупереджений і своєчасний розгляд i вирішення цивільних справ із метою захисту порушених, невизнаних або оспорюваних прав, свобод чи інтересів фізичних осіб, прав та інтересів юридичних осіб, інтересів держави (ст. 1 ЦПК 2019 р.).

Суд, приймаючи рішення, відновлює законність у взаємовідносинах сторін: або визнає права позивача, порушення відповідача, або відхиляє вимоги позивача, захищаючи тим самим права відповідача.

Рішення суду може виступати як публічний акт, відомий невизначеному колу осіб, коли результати судових рішень з окремих цивільних справ виходять друком. Тим самим рішення суду здійснює профілактичний вплив 
і показує, як не треба чинити у тій чи іншій ситуації. Судове рішення як акт правосуддя виховує громадян України у дусі поваги до закону, примушує їх правильно будувати свої відносини як між собою, так і між організаціями та державою загалом.

Значення ухвал суду першої інстанції зумовлене вирішенням питань, спрямованих на виникнення, розвиток або припинення цивільних процесуальних правовідносин, на створення належних умов для всебічного, повного й об'єктивного розгляду та вирішення справи, реалізацію і захист процесуальних прав суб'єктів цивільних процесуальних правовідносин.

Таким чином, важливість постанов суду першої інстанції може бути реалізована лише тоді, коли вони зможуть виконати задачі цивільного судочинства, коли вони будуть правомірними, а це, зрештою залежить від виконання судом усіх вимог, встановлених законом.

Насамперед розглянемо додержання процесуальної форми та змісту судового рішення, яке є однією з обов'язкових вимог цивільно-процесуального законодавства, що забезпечує здійснення правосуддя з конкретної цивільної справи.

У науці цивільного процесуального права поняття процесуальної форми та змісту судового рішення розглядалися у працях М.А. Гурвіча, М.Г. Авдюкова, С.Г. Пушкаря та ін.

Так, на думку М.А. Гурвіча, природа судового рішення спрямована на діяльність суду у ході розгляду і вирішення справи. Винесення судового рішення відбувається у ході розгляду і вирішення справи. Шлях цього розгляду визначений процесуальним законом і становить процесуальну форму. В абстрактному вигляді це об'єктивне цивільне процесуальне право, а у конкретизованому у певній справі - форма цього процесу, або цивільне процесуальне правовідношення ${ }^{6}$.

М.А. Гурвіч вважав, що характерним у цивільному процесі стимулом, який виникає у конкретній процесуальній формі 3 подальшим спрямуванням регулювання цього процесу і його нормальним завершенням у судовому рішенні, є одностороннє волевиявлення зацікавленої особи. Праця М.А. Гурвіча присвячена переважно судовому рішенню як акту державної влади, акту державної функції правосуддя, що $є$ імперативом, містить волю і наказ. Автор приділяє увагу праву й обов'язку суду виносити рішення, але повною мірою не розкриває поняття форми та змісту судового рішення. Тому цю роботу ми можемо розглядати як таку, що допомогла з'ясувати інститут судового рішення, його юридичну природу, визначити роль судового рішення у процесуальній теорії.

\footnotetext{
${ }^{6}$ Гурвич М.А. Судебное решение. Теоретические проблемы. Москва : Юрид. лит., 1976. С. 5.
} 
М.Г. Авдюков форму та зміст судового рішення розглядав більш широко, звертаючи увагу на сутність, порядок постановлення, зміст і законну силу судового рішення. Автор вказує на письмову форму судового рішення. Рішення, не втілене у письмову форму, не є винесеним. Усний зміст сутності спору між особами, хоча б він і виходив від суду, не спричиняє жодних юридичних наслідків ${ }^{7}$. Крім того, дослідник розглядає структуру судового рішення: вступну, описову, мотивувальну і регулятивну частини. Відсутність описової частини не дозволяє перевірити правильність висновків суду зі справи, оскільки з тексту рішення суду не буде відомо, стосовно яких вимог осіб, які беруть участь у справі, воно винесене і на яких підставах ці вимоги заявлялися. Без описової частини не може бути належного мотивування рішення. Викладення мотивів у тексті рішення надає останньому переконливість і робить висновок суду зі справи зрозумілим для всіх. Резолютивна частина рішення повинна не випливати із враження суду, а бути фактично і юридично обгрунтованою. Ця частина має містити у собі відповідь суду на позовні вимоги. М.Г. Авдюков робить висновок, що форма і зміст судового рішення - це невідривні поняття, що є обгрунтуванням правильного складання процесуального документа - акта правосуддя у цивільних справах, яким $\epsilon$ судове рішення.

Є.Г. Пушкар розглядає форму і зміст судового рішення як остаточний результат діяльності суду першої інстанції. Цим процесуальним документом завершується вся діяльність суду, спрямована на захист порушеного чи оспорюваного суб'єктивного права чи охоронюваного законом інтересу сторін ${ }^{8}$. Судове рішення як процесуальний документ має велике практичне значення, закріплюючи висновок суду як акт правосуддя. Також воно як процесуальний документ виконує допоміжну функцію - роз'яснює особам, котрі беруть участь у справі, чому суд дійшов саме таких висновків. Виходячи 3 усього зазначеного, С.Г. Пушкар робить висновок, що судове рішення як процесуальний документ $є$ засобом пропаганди правових знань серед населення, де судове рішення виражає загальну тенденцію розвитку цивільного законодавства.

Таким чином, судове рішення є підсумковим процесуальним документом, де форма і зміст становлять нерозривну єдність, у якій зміст у кожному своєму прояві грає визначальну роль. Судове рішення як процесуальний документ $\epsilon$ тою формою, у якій викладається судове рішення як акт правосуддя.

Слід зазначити, що поряд зі становленням і розвитком процесуального законодавства судове рішення як процесуальний документ теж пройшло певну еволюцію. Глава 7 Статуту цивільного судочинства 1864 р. була

\footnotetext{
${ }^{7}$ Авдюков М.Г. Судебное решение. Москва : Юрид. лит., 1959. С. 36.

${ }^{8}$ Пушкарь Е.Г. Исковое производство в советском гражданском процессе. Львов : Изд-во при Львовском ун-те, 1978. С. 18.
} 
повністю присвячена тогочасному судовому рішенню. Так, ст. 142 цього Статуту вказувала на зміст судового рішення, викладення його в остаточній формі. Воно повинно містити в собі: зазначення року, місяця і числа, коли ухвалено рішення; звання, прізвища й ініціали «тяжущихся», короткий виклад обставин справи $з$ наведенням вимог «тяжущихся», сутність рішення i міркувань, на яких воно засноване; зазначення витрат провадження, присуджених виправданою стороною; вказівка, чи підлягає рішення негайному виконанню; підпис Мирового судді ${ }^{9}$.

Такий правовий вигляд мало судове рішення, передбачене першим вітчизняним нормативно-правовим актом цивільного процесу. Він мав достатньо досконалий для того часу зміст, оскільки завершував хід судового процесу.

У такому вигляді правові вимоги до судового рішення існували до радянських часів.

Першим вітчизняним процесуальним законом радянського періоду став ЦПК УРСР 1924 р., який містив також у собі правові норми-вимоги до змісту судового рішення. Так, ст. 175 ЦПК УРСР 1924 р. передбачала, що «постановлене рішення викладається у письмовій формі головою чи одним із членів складу суду і підписується усіма суддям». Ст. 176 ЦПК УРСР 1924 р. передбачала зміст судового рішення, яке повинно містити в собі: час постановлення; склад суду і найменування сторін; зазначення предмета спору; підставу рішення і закони, якими суд керувався; зміст винесеного по справі рішення і порядок його виконання; порядок оскарження; розподіл судових витрат ${ }^{10}$. Такий правовий вигляд мало судове рішення, передбачене ЦПК 1924 р., яке проіснувало без змін до 1963 р.

У липні 1963 р. був прийнятий ЦПК УРСР, котрий набрав чинності 3 1 січня 1964 р. Цей Кодекс відрізнявся від інших тим, що мав своєрідне подання змісту судового рішення. Саме в цьому Кодексі вперше зазначалися усі частини судового рішення у повному і визначеному вигляді, що дало змогу з'ясувати, яким повинно бути судове рішення як процесуальний документ. Ст. 203 ЦПК 1963 р. передбачає, що рішення складається зі вступної, описової, мотивувальної та резолютивної частин. У вступній частині зазначається час і місце постановлення рішення, найменування суду, котрий його постановив, склад суду, прізвище секретаря судового засідання, прізвище прокурора, який брав участь у справі, найменування сторін та інших осіб, котрі брали участь у справі, представника громадської організації.

\footnotetext{
9 Устав гражданского судопроизводства 1864 года / Проект новой редакции Устава гражданского судопроизводства. Санкт-Петербург : Сенатская типография, 1900. С. 231.

10 Цивільний процесуальний закон радянського періоду ЦПК УРСР (текст і практичний коментарій). Київ : Юридичне видавництво, 1925. С. 165, 166.
} 
Описова частина повинна містити в собі вказівку на вимоги позивача, заперечення відповідача і пояснення інших осіб, що беруть участь у справі.

У мотивувальній частині рішення слід було навести обставини справи, встановлені судом, докази, на яких грунтуються висновки суду, доводи, за яких суд відхиляє ті чи інші докази, а також закони, якими керувався суд.

Резолютивна частина рішення має містити в собі висновок суду про задоволення позову або про відмову в позові повністю чи частково, вказівку на розподіл судових витрат, строк і порядок оскарження рішення ${ }^{11}$.

У 1996 р., тепер вже у ЦПК України, було змінено ст. 203. Редакція цієї статті вказувала не на структуру рішення суду першої інстанції, а на його реквізити, як це вказувалося у ЦПК 1924 р. ${ }^{12}$. Навряд це подання змісту судового рішення можна було назвати кроком вперед. На наш погляд, викладення змісту судового рішення з позначенням усіх чотирьох частин вступної, описової, мотивувальної та резолютивної, кожна з яких повинна супроводжуватися певними реквізитами, що належать тільки їй, - допомагає закону згідно з цією статтею визначити зміст (суть), правову форму рішення, регламентувати порядок його викладення, послідовність розміщення реквізитів, перетворюючи відповідний текст на процесуальний документ із дотриманням змісту судового рішення як акта правосуддя.

Викладення змісту судового рішення із зазначенням вступної, описової, мотивувальної та регулятивної частин об'єднує його в єдиний складний зміст, куди входять два розділення: на процесуальний документ і акт правосуддя. Це не призводить до непорозуміння при комплексному розгляді змісту цього процесуального документа, в якому цей акт втілено. Це положення, зазначене у ст. 215 ЦПК 2019 р., передбачає саме таке викладення змісту судового рішення, яке має в собі вимоги як процесуального документа, так і вимоги акта правосуддя. Ця зміна, на нашу думку, дає більш чітке уявлення про судове рішення в ЦПК України, що полегшить роботу суду під час складання цього процесуального документа, оформлення його із застосуванням вимог цієї статті, а також дасть можливість спростити процес ознайомлення з ним для осіб, які брали участь у справі.

Таким чином, невеликий історичний екскурс щодо розвитку форми та змісту судового рішення дає змогу зробити висновок, що на всіх історичних етапах розвитку процесуального законодавства законодавець удосконалював норми, які регулювали зміст судового рішення, порядок його оформлення. Судове рішення як процесуальний документ $є$ найважливішою формою акта правосуддя, вдосконалення якого чинить лише позитивний вплив на громадянина та законність і обгрунтованість судового рішення.

\footnotetext{
${ }^{11}$ Гражданский процесуальний кодекс Украинской ССР. Киев : Госюриздат УССР, 1964. С. $81,82$.

${ }^{12}$ Цивільний процесуальний закон радянського періоду ЦПК УРСР (текст і практичний коментарій). Київ : Юридичне видавництво, 1925. С. 201.
} 
Слід мати на увазі, що як ЦПК 1963 р., так і ЦПК 2019 р. не передбачена форма складання судового рішення як процесуального документа, а також способи та технічні засоби, які можуть бути застосовані під час оформлення судового рішення, хоча $\epsilon$ певні вимоги, що висуваються до цього процесуального документа. Насамперед текст рішення має бути написаний грамотно, без помилок і 3 дотриманням стилю офіційних документів. Речення слід добирати короткі та прості. Перехід від однієї фрази до іншої повинен бути логічним і природним. Все це сприяє ясності та дохідливості судового документа.

Так, I.M. Зайцев зазначає, що вимоги діловодства у сфері правосуддя нечисленні, елементарні та безспірні. Не всі вони включені до ЦПК України. Так, навряд доцільно нормативно виділяти обов'язки судді граматично правильно оформляти судове рішення, потрібне лише належне ставлення суддів до службових обов'язків ${ }^{13}$.

Спосіб виготовлення тексту становить зміст письмового волевиявлення суду, тому текст цього процесуального документа повинен відповідати усім вимогам до форми судового рішення.

Тому вважаємо, що необхідно ст. 215 ЦПК 2019 р. доповнити положенням про необхідність викладати судове рішення чітким машинописним текстом. Це узаконить форму судового рішення як процесуального документа й у майбутньому полегшить роботу суддів, оскільки зараз у судовій практиці дедалі більшу частку займають письмові документи у вигляді машинописного тексту, а також сприятиме цивілізованому оформленню копій рішень, які видаються сторонами, бо саме за ними оцінюється ділова каліфікація працівників суду.

М.Й. Штефан зазначає: сутність судового рішення в тому, що воно $є$ основним i найважливішим актом правосуддя, постановленим ім'ям України і спрямованим на захист прав, свобод і законних інтересів громадян та організацій, держаних і громадських інтересів, зміцнення законності та правопорядку, на запобігання правопорушенням, виховання громадян і посадових осіб у дусі поваги до Конституції, законів України, честі та гідності людини ${ }^{14}$.

Суд, постановляючи рішення, тим самим реалізує судову владу, тому воно і повинне розглядатися насамперед як акт реалізації судової влади. Аналіз процесуальних властивостей судового рішення, процедури його винесення, проголошення, реалізації тощо прямо залежить від правильного визначення юридичного та соціального статуту цього документа.

\footnotetext{
13 Зайцев И.Н. Судебное решение как процесуальный документ. Рос. Юстицияя. 1995. № 4. С. 20.

${ }^{14}$ Штефан М.Й. Цивільний процес : підручник. Київ : Ін Юре, 1997. С. 356.
} 
Ст. 7 ЦПК 2019 р. закріплює правило, згідно 3 яким судочинство здійснюється державною мовою, і передбачає положення, за яким судові документи складаються державною мовою. Таким чином, ст. 7 ЦПК 2019 р. формулює незаперечні правила, вони кваліфікуються як принцип мови судочинства, що застосовується на всіх стадіях цивільного процесу. Ця редакція статті є продуктивною, оскільки відразу зникають суперечки під час складання судового рішення, його проголошення й ознайомлення з ним.

Рішення за формою має бути викладене письмово, а за змістом відповідати ст. 215 ЦПК 2019 р. Як відомо, в українському законодавстві зміст судового рішення ділять на чотири частини (вступну, описову, мотивувальну і резолютивну). Кожна 3 них обов'язково повинна бути наявна у судовому рішенні як процесуальному документі.

Таким чином, постановляючи рішення, суд тим самим реалізує судову владу, тому воно має розглядатися як акт реалізації останньої. Аналіз процесуальних властивостей судового рішення, процедури його винесення, проголошення, реалізації тощо прямо залежить від правильного визначення юридичного та соціального статусу цього документа.

\section{2. Процесуальний зміст судового рішення}

Рішення за формою має бути викладене письмово, а за змістом відповідати ст. 215 ЦПК 2019 р. Як відомо, в українському законодавстві зміст судового рішення ділять на чотири частини (вступну, описову, мотивувальну i резолютивну). Кожна 3 них обов'язково повинна бути наявна у судовому рішенні як процесуальному документі.

Вступна - це перша початкова частина, яка розпочинається найменуванням документа і вказівкою назви держави, від імені якої воно ухвалюється.

У вступній частині рішення згідно з чинним законодавством визначаються: час і місце його ухвалення; найменування суду, котрий ухвалив рішення; прізвища й ініціали судді (суддів - за колегіального розгляду); прізвище й ініціали секретаря судового засідання; імена (найменування) сторін та інших осіб, котрі брали участь у справі; предмет позовних вимог. Такі вимоги цивільного процесуального закону не $\epsilon$ надмірною формальністю. Так, наприклад, вказівка на найменування суду, що постановив рішення, $\epsilon$ гарантом перевірки процесуальних дій судів першої інстанції. За відсутності найменування суду у тексті судового рішення суди вищої інстанції не можуть визначити адресну спрямованість цього процесуального документа.

Усі ці вимоги до вступної частини закріплені у ст. 215 ЦПК 2019 р., крім одного положення - «у якому засіданні розглядається справа: у відкритому чи закритому». Оскільки це положення зазначається у юридичній літературі та використовується на практиці у суді, на нашу думку, необхідно його 
остаточно закріпити у ст. 215 ЦПК 2004 р., що узаконить ще одну з вимог вступної частини судового рішення і надалі не викликатиме суперечок у суді щодо фіксування цього положення у процесуальному документі.

Щодо предмета позовних вимог вважаємо, що це положення вкрай необхідне, оскільки суд (суддя), а також особи, які беруть участь у справі, повинні розуміти предмет позовних вимог позивача з ходом усього судового розгляду і самим винесеним судовим рішенням.

Описова частина судового рішення повинна містити: узагальнений виклад позиції відповідача; пояснення осіб, котрі беруть участь у справі; інші докази, досліджені судом.

Відсутність описової частини рішення не дасть змоги перевірити правильність висновків суду зі справи, оскільки з тексту рішення не буде відомо позиції відповідача у справі, пояснень осіб, які беруть участь у справі, та доказів, досліджених судом. Без описової частини не може бути мотивувальної.

У цій частині, на наш погляд, дуже важливим для суду $є$ детальне викладення позиції відповідача, пояснень осіб, котрі беруть участь у справі, та доказів, які досліджувалися судом.

Недопустимі у тексті рішення повтори. Факти мають бути викладені один раз, так повно і зрозуміло, щоб не викликати сумнівів. Між тим нерідко фабула справи повторюється - спочатку суд в описовій частині детально викладає зміст позовної заяви та заперечення відповідача, а потім у мотивувальній частині наводить ті самі відомості. Подібна практика не відповідає ні вимогам діловодства, ні законодавству.

У мотивувальній частині рішення подаються всі міркування суду, на яких грунтується рішення у справі. Це фактичні та юридичні мотиви висновків суду у справі. У них наводяться: встановлені судом обставини та визначені відповідно до них правовідносини; мотиви, з яких суд вважає встановленою наявність або відсутність фактів, якими обгрунтовувалися вимоги чи заперечення, бере до уваги або відхиляє докази, застосовує зазначені в рішенні нормативно-правові акти; чи були порушені, не визнані або оспорювані права, свободи чи інтереси, по захист яких особа звернулася до суду, а якщо були, то ким; назви, статті, їі частини, абзацу, пункту, підпункту закону, на підставі якого вирішено справу, а також процесуального закону, яким суд керувався.

Ніщо, у т. ч. й визнання відповідачем позову, не звільняє суд від обов'язку з'ясувати дійсні права та взаємовідносини сторін. Правом суду $є$ те, що засновано на остаточно встановлених фактах, а визнання відповідачем позову може і не відповідати фактам об'єктивної дійсності. 
Тому у разі визнання відповідачем позову та в інших випадках висновки суду слід мотивувати.

Мотиви - це всі ті міркування суду, з яких він дійшов свого рішення. Викладення мотивів у тексті рішення надає останньому переконливості та робить висновок суду зі справи більш ясним.

Традиційним у цивільно-процесуальній літературі $\epsilon$ твердження про внутрішню переконаність суддів у істинності чи хибності шуканих фактів. Основу внутрішнього переконання становить сукупність фактів, встановлених у справі. Предмет внутрішньої переконаності повинен бути розширений за рахунок доказів і правильного вирішення справи по суті.

У мотивувальній частині суд насамперед повинен вирішити, які саме юридичні факти, що мають важливе значення для справи, він вважає встановленими, а які - невстановленими. Фактичне обгрунтування рішення складається із міркувань про факти підстав позову, а також суджень про факти, покладені в основу заперечення проти позову.

Обставини, вказані сторонами, суд порівнює 3 тими передбаченими нормами матеріального права, фактичним складом, який є необхідним для задоволення позовної вимоги. Внаслідок порівнянь суд, з одного боку, викреслює обставини, які не стосуються цієї справи, 3 іншого - якщо позивач і відповідач не зробили посилань на усі значимі факти, суд 3 особистої ініціативи вводить відсутні факти у предмет доказування, а потім висловлює про них судження під час обгрунтування рішення.

Підкріплення висновків суду про юридичні факти доказами у кожному рішенні у цивільній справі має свої особливості. Тому, на нашу думку, необхідно висловити загальні положення стосовно мотивування судового рішення у юридичній літературі. По-перше, рішення може бути обгрунтованим лише матеріалами, які розглядалися у судовому засіданні. Суд не має права залучати для обгрунтування рішення матеріали, що не були предметом вивчення у судовому засіданні. Мотивування має містити у собі аналіз та оцінку усіх доказів у справі. По-друге, посилання на докази та їх оцінка повинні бути конкретними. Відмовляючись від тих чи інших доказів, представлених сторонами, суд повинен обов'язково вказати у рішенні, чому саме ці докази ним відхилені. По-третє, усі докази, в т. ч. і висновки експертів, оцінюються. виходячи із внутрішньої переконаності суддів, яке засновується на розгляді усіх обставин справи у їх сукупності.

У мотивувальній частині рішення повинні бути посилання на норми матеріального права, якими суд керується у вирішенні справи. Суд вирішує, чи відповідають вимоги позивача закону, і якому саме. Ці моменти відображені та закріплені у мотивувальній частині рішення. Правове 
обгрунтування рішення є зовнішнім відображенням того, що під час розгляду справи суд використовував тільки закон.

Чітке посилання на норми матеріального права робить рішення суду авторитетним, переконливим і ясним, що надалі полегшить роботу вищестоящих судів під час вивчення справи. Застосування тих чи інших статей процесуального закону свідчить про виконання судом визначених у них вимог, про чітке уявлення суддями своїх задач і процесуальних засобів їх реалізації.

Таким чином, правова цінність мотивувальної частини визначається тим, що у цій частині рішення суд відповідає на питання, чому ті чи інші докази визнані достовірними та які правові висновки випливають із такого аналізу доказів. Іншими словами, у мотивувальній частині суд підводить підсумок досліджування доказів - розгляду цивільної справи по суті. Відсутність мотивів, а також недоліки у їх викладенні обмежують можливість оскарження й опротестування рішення (неясність доводів суду).

Ст. 215 ЦПК 2019 р. зазначає мотиви, з яких суд дійшов висновків, і закон, яким керувався суд, постановляючи ухвалу. Це положення в обов'язковому порядку зобов'язує суди викладати свої фактичні та юридичні висновки зі справи. Мотиви повинні наводити обставини справи, доводи, за якими суд відхиляє ті чи інші докази; закони, якими керувався суд. Іншими словами, мотивувальна частини судового рішення як процесуального акта-документа $€$ «дзеркалом резолютивної частини», оскільки відображає, чому саме завершальні висновки суду по суті справи такі, а не інші. Це дає можливість при ознайомленні з цивільною справою вищестоящим судом більш ретельно перевірити хід і завершення процесу, застосування судом норм матеріального і процесуального права під час вирішення цивільної справи, що полегшує працю вищестоящих судів у разі перегляду справи.

Ст. 215 ЦПК 2019 р. зазначає, що у резолютивній частині повинні бути: висновки суду про задоволення позову або відмову в позові повністю чи частково; висновки суду по суті позовних вимог; розподіл судових витрат; строк і порядок набрання рішенням законної сили та його оскарження. Резолютивна частина повинна завжди викладатися з урахуванням конкретних обставин і відповідно до норм матеріального права, яким суд керувався.

Резолютивна частина характеризується відповідями на всі правові питання, поставлені у позовній заяві. Ці відповіді повинні випливати зі встановлених фактичних обставин, бути вичерпними, визначеними та безумовними. Вичерпними будуть рішення, в яких судом дається повна відповідь на всі передані на його вирішення правові питання. Вимога визначеності полягає у тому, що рішення суду повинно дати чітку і конкретну відповідь на всі поставлені перед ним питання; безумовності - у тому, що висновки, зроблені в рішенні, не повинні включати умови, які б поставили його виконання 
у залежність від їх настання. Таким чином, резолютивна частина повинна містити у собі висновки по суті розглянутих вимог.

Суд має право включити у резолютивну частину і додаткові положення, спрямовані на створення конкретних умов реалізації рішення, визначити порядок його виконання, надати відстрочку або розстрочку виконання, вжити заходів для забезпечення його виконання, про що зазначає у рішенні.

Рішення суду ухвалюється в нарадчій кімнаті з додержанням її таємниці, викладається у письмовій формі головуючим або одним із суддів при колегіальному розгляді справи та підписується всім складом суду, який бере участь у постановлені рішення. Постановлене судом рішення проголошується прилюдно. Головуючий роз'яснює зміст рішення, порядок і строк його оскарження. Після проголошення рішення суд, котрий його ухвалив, не може сам скасувати або змінити це рішення.

Таким чином, проведений аналіз питань щодо форми та змісту судового рішення дозволяє зробити певні висновки. Додержання процесуальної форми та змісту судового рішення є однією з обов'язкових вимог цивільнопроцесуального законодавства, що забезпечує винесення суддею законного й обгрунтованого судового рішення та правильного оформлення цього процесуального документа.

Дослідження і подальше вдосконалення судового рішення як основного i найважливішого акта правосуддя має велике значення для захисту прав $\mathrm{i}$ свобод та законних інтересів громадян і організацій, державних і громадських інтересів. Подальше вдосконалення ЦПК України, на наш погляд, зменшить кількість недоліків і помилок у складанні судом цього процесуального документа, полегшить працю суддів i зробить ознайомлення із цим процесуальним документом для громадянина більш ясним і зрозумілим.

Як ми вже зазначали, характеристика судового рішення має науковопрактичне значення 3 погляду як процесуального документа із зовнішнім виявом акта правосуддя, так і його змісту як акта застосування права. Вказані складники поняття судового рішення не суперечать один одному, навпаки, вони тісно взаємопов'язані, однак кожен із них відносно самостійний. Якщо, наприклад, узяти судове рішення як акт судової влади, то воно повинне не залежати від політики держави, а лише бути проявом правосуддя (у формі акта), а судове рішення як процесуальний документ за формою обов'язково має відповідати правовим вимогам, які ставляться до нього процесуальним законодавством (у формі документа).

Щоб судове рішення виконувало функцію захисту порушеного права чи охоронюваного законом інтересу громадян i організацій, воно має відповідати певним вимогам. Так, рішення суду повинне бути законним i обгрунтованим. 
На нашу думку, без дослідження таких основних вимог судового рішення, як законність і обгрунтованість, повнота, визначеність, форма, ясність i точність, неможливо розкрити повністю зміст судового рішення як основного акта правосуддя.

Судове рішення як результат діяльності суду щодо встановлення фактичних обставин і вирішення спору по суті $\epsilon$ актом, що забезпечує реалізацію прав та обов'язків у реальній поведінці суб'єктів.

Пізнання спірних правовідносин складається із двох взаємопов'язаних $\mathrm{i}$ визначальних елементів: із визначення правової норми, яка регулює спірні відносини, їх тлумачення і застосування, а також з установлення наявності чи відсутності передбачених цією нормою юридичних фактів. Перший елемент визначає законність судового рішення, а другий - його обгрунтованість.

Між законністю й обгрунтованістю судового рішення існує тісний зв'язок. Це дві сторони одного й того самого явища. Цивільний процесуальний закон вимагає, щоб судове рішення було обгрунтованим, а це означає, що необгрунтоване рішення $є$ водночас і незаконним. Ці два поняття взаємопов'язані, але не тотожні.

На відміну від обгрунтованості, законність як передумова набрання судовим рішенням законної сил означає, що ми повинні враховувати чинні норми матеріального та процесуального права. На наш погляд, не слід протиставляти ці дві норми. Якість рішення визначається правильним застосуванням судом матеріально-правових норм, дотриманням норм процесуального права. Судове рішення буде відповідати вимозі законності тільки в тому разі, якщо при розгляді та вирішенні судової справи були точно та неухильно дотримані норми матеріального та процесуального права.

Велике значення має дотримання судом норм процесуального права. Цивільне процесуальне законодавство регулює відносини, які виникають між судом, сторонами, третіми особами, а також іншими учасниками процесу під час розгляду та вирішення конкретної цивільно-правової справи, тобто у сфері здійснення правосуддя з цивільних справ. Зв'язок між матеріальними та процесуальними цивільними правовідносинами визначається тісним взаємозв'язком між матеріальним і процесуальним правом. Поряд із тим цивільні процесуальні правовідносини суттєво відрізняються від матеріальних. Ця відмінність полягає у тому, що процесуальні правовідносини є владними правовідносинами, й одним із головних суб'єктів цих правовідносин $є$ такий орган влади, як суд.

У літературі із процесуального права підтримується позиція, за якою «сила влади» передається судовому рішенню на основі норми права. Саме норма права, на думку багатьох процесуалістів, забезпечує застосовування 
примусових заходів із боку суду. Саме за цією ознакою процесуальні правовідносини слід відрізняти від цивільних.

Таким чином, застосовуючи норми процесуального права, суд визначає належну поведінку суб'єктів процесуальних правовідносин і тим самим створює передумови для належного розвитку процесу i правильного вирішення спору.

На наш погляд, законність судового рішення залежить не стільки від дотримання процесуальних норм сторонами, третіми особами та іншими суб'єктами процесуальних правовідносин, скільки від суду. Процесуальні порушення 3 боку суду не можуть бути усунені іншими суб'єктами процесуальних правовідносин.

Помилка з боку суду зазвичай приводить до скасування судового рішення як незаконного та необгрунтованого. Тому для суду дуже важливо правильно визначити правову норму, яка регулює спірні відносини, а за необхідності - й усієї сукупності правових норм.

Регулюючи правовідносини за допомогою правових норм, суд $є$ утіленням влади, за допомогою якої судове рішення набуває законної сили. Вважаємо, що законна сила судового рішення проявляється як авторитет судової влади та наділяє відповідний акт такими характерними властивостями, як обов'язковість, винятковість, преюдиціальність і здійснимість (виконання).

Обов'язковість судового рішення, яке набрало законної сили, має значення для усіх осіб, у т. ч. для державних органів і окремих громадян, дія яких визначається правами, підтвердженими судовим рішенням стосовно інших осіб. Усі державні органи, посадові особи й окремі громадяни повинні сприяти виконанню рішення суду. Обов'язковість - це ніби зібрані у єдиному фокусі нормативність і примусовість права.

Винятковість судового рішення проявляється у тому, що у разі набрання рішенням законної сили сторони й інші особи, котрі беруть участь у справі, а також їхні правонаступники не можуть знову заявляти у суді ті самі позовні вимоги 3 тих самих підстав, а також оспорювати в іншому процесі встановлені судом факти та правовідносини.

Преюдиціальність - це неможливість для осіб, які брали участь у справі, та їхніх правонаступників оспорювати, а для суду - неможливість досліджувати в іншому процесі факти та правовідносини, встановлені рішенням суду, що набрало законної сили.

Таким чином, законність судового рішення цілком залежить від правильного виявлення правової норми, яку суд застосовує у судовому рішенні. Процес відшукування правової норми, на наш погляд, повинен починатися для суду 3 моменту вирішення судом питання про право на пред'явлення позову, причому початковими даними будуть обставини, що $\epsilon$ 
у позові. Без застосування правильної правової норми немає правосуддя. Тому буде необхідно, на нашу думку, доповнити ст. 119 ЦПК 2019 р. положенням про обов'язок позивача вказувати на правову норму, котра $\epsilon$ підставою порушення справи у його спорі. Ми вважаємо, що це дасть змогу суду правильно уявити характер спірного правовідношення й остаточно вивчити обставини справи.

Обгрунтованість $\epsilon$ другою властивістю судового рішення. У судовій практиці, як і в теорії цивільного процесу, склалося двояке розуміння обгрунтованості судового рішення. У широкому розумінні це правильність судового рішення, а у вузькому - коло юридичних фактів, які підлягають дослідженню.

На наш погляд, вимогою обгрунтованості судового рішення є правильне встановлення юридичних фактів, що вказують на виникнення, зміну чи припинення правовідносин, достовірність висновків щодо кожного факту.

Судове рішення, як і всяка інша постанова суду, має грунтуватися на достовірно встановлених юридичних фактах, які мають значення для розгляду справи. Засобом для пізнання обставин спірного правовідношення повинні бути докази. Для пізнання будь-якого факту, що має значення, суд повинен виділити докази, котрі стосуються цього факту.

Висновки, які не грунтуються на доказах, спричиняють скасування судового рішення як необгрунтованого. Доказова діяльність повинна починатися з моменту подання позову. Суду треба з'ясувати наявність у позовній заяві посилань на докази, що підтверджують позов. Під час розгляду справи суд досліджує не тільки докази позивача, а й докази відповідача.

Таким чином, важливою умовою для пізнання судом юридичних фактів $\epsilon$ повнота доказів. Повнота доказового матеріалу залежить від доказової діяльності осіб, котрі беруть участь у розгляді справи.

Істинність висновків суду залежить також від якісності зібраних доказів, які залучаються до справи, адже докази не повинні викликати сумніви щодо своєї достовірності. Достовірність доказів має визначатися якістю джерела, із котрого витікають дані щодо факту, який досліджується. Наприклад, якщо таким джерелом $є$ документ, то він має відповідати певним вимогам.

Слід зазначити, що оцінка доказів - дуже складний і довгий процес розумової діяльності суду, і критерієм оцінки доказів у справі все ж таки залишається внутрішнє переконання. Давати оцінку доказам означає не залежати від формальних умов, робити висновок про факти, які досліджуються, без стороннього впливу; під час винесення судового рішення суддя повинен робити висновки на основні сукупності усіх обставин справи за допомогою тлумачення правової норми, що регулює ці спірні правовідносини. 
Повнота судового рішення означає, що у судовому рішенні повинні бути вирішені всі заявлені вимоги, вказано їх розмір, а також вирішене питання про негайне виконання і судові витрати. Повним слід вважати таке рішення, в якому вирішено питання не тільки про право, але й про розмір присудженого. У рішенні суд повинен вказати, хто має право, а хто несе обов'язок, у чому конкретно вони полягають і щодо якого об'єкта. Суд зобов'язаний вирішити усі вимоги, тільки тоді рішення набуде повноти, що веде до негайного його виконання.

Визначеність судового рішення необхідна, бо вона вказує на наявність або відсутність прав і обов'язків сторін та інших осіб, які беруть участь у справі. Визначеність потрібна для усунення сумнівів у правовідносинах між сторонами. Вимога визначеності впливає на недопустимість альтернативних рішень.

Згідно 3 вимогою ясності в рішенні суд повинен вказати повну i правильну назву сторін та інших осіб, котрі беруть участь у справі, чітко сформулювати свої висновки щодо їхніх прав і обов'язків, щоб рішення суду було належним чином виконане.

Точність як вимога до судового рішення полягає у безпомилковому викладенні змісту судового рішення, а також здійсненні безпомилкових підрахунків.

Отже, зміст судового рішення є великою кількістю вимог до дотримання закону у діяльності суду під час винесення рішення. Зміст процесуальної форми судового рішення впливає на винесене судове рішення, його законність і обгрунтованість для всіх учасників судового процесу.

\section{ВИСНОВКИ}

Таким чином, розглядаючи усі вимоги до судового рішення, можна зробити висновок, що цей процесуальний акт-документ є багатогранним, його структура постійно змінюється та доповнюється відповідно до чинного законодавства. Вивчення вимог щодо судового рішення як основного акта правосуддя має велике значення для формування вчення про судове рішення.

На наш погляд, законна сила рішення проявляється як авторитет судової влади, тобто це особлива правова дія суду, яка засновується на нормах матеріального та процесуального права.

Судове рішення - це постанова суду, котра вирішує цивільну справу по суті, й одночасно правозастосовчий акт і процесуальний документ. За допомогою цього рішення суд вирішує спірні матеріально-правові відносини та пропонує суб'єктам цих відносин оптимальний варіант індивідуальної поведінки. 
Таким чином, проведене дослідження інституту судового рішення дозволяє зробити висновки, які допоможуть з'ясувати правову природу й особливість цього акта правосуддя, котрим закінчується розгляд і вирішення цивільної справи в суді.

Основним завданням судового рішення є захист законних прав, свобод та інтересів громадян, встановлення соціальної справедливості. Судове рішення як акт соціальної справедливості сприяє зміцненню етичних засад цивільного судочинства, оскільки справедливе рішення викликає повагу до права, закону та суду як гаранта утвердження законних і справедливих відносин у суспільстві.

Тобто характер і особливості процесуальної форми визначаються змістом, втіленим у цю форму. Процесуальна форма і зміст $\epsilon$ формою судової діяльності та відносин, які виникають із цієї діяльності, оскільки її особливості визначаються змістом викладення юридичного матеріалу розгляду справи за допомогою юридичної техніки ведення судового процесу, змістом діяльності суду.

\section{АНОТАЦІЯ}

Судове рішення - це ключовий інститут цивільного процесуального права. У зв'язку зі змінами у правовій системі та цивільному судочинстві $\epsilon$ потреба звернутися до судового рішення та до його процесуальної форми та змісту. Визначено, що ефективність вирішення цивільної справи, законність та обгрунтованість винесеного судового рішення судом у майбутньому залежить насамперед від певної юридичної техніки, документування як основних механізмів діловодства роботи суду, що охоплюють всі аспекти судової діяльності згідно зі стадійним рухом цивільної справи. Доведена певна взаємозалежність у цивільному судочинстві таких понять, як усне викладення інформації у суді, їі документальне оформлення та фіксація судового процесу. Ведення, оформлення, розгляд, вирішення судової справи насамперед залежить від суду (судді), котрий планує розгляд конкретної справи. Планування роботи в судах, на відміну від інших органів державної влади, має свою специфіку, пов'язану із процесуальним статусом цього органу. Суддя, приймаючи цивільну справу до розгляду, повинен спланувати іiі можливий хід і використання певних нормативних актів цивільного процесу, ii оформлення та фіксацію. Це і відображатиме процесуальну форму і зміст цього судового розгляду.

\section{ЛITЕРАТУРА}

1. Конституція України від 28 червня 1996 р. Відомості Верховної Ради України. 1996. № 30. Ст. 141. 
2. Організація роботи суду : навчальний посібник / I.Є. Марочкін, Л.М. Москвіч, О.М. Овчаренко та ін. ; за заг. ред. І.С. Марочкіна. Харків : Право, 2012. $256 \mathrm{c}$.

3. Онищук I.I. Техніка юридичного письма в нормативно-правових актах : монографія. Івано-Франківськ : Лабораторія академічних досліджень правового регулювання та юридичної техніки, 2014. 228 с.

4. Корж А.В. Документація право ділової форми : навчальний посібник : лекції та зразки документів / Ін-т держави і права ім. В.М. Корецького НАН / Нац. акад. внутрішніх справ України. Київ, 2002231 с.

5. Гурвич М.А. Решение советского суда в исковом производстве. Москва : Центр типографии МО СССР им. К.С. Ворошилова, 1955. 128 с.

6. Гурвич М.А. Судебное решение. Теоретические проблемы. Москва : Юрид. лит., 1976. 176 с.

7. Авдюков М.Г. Судебное решение. Москва : Юрид. лит., 1959. 179 с.

8. Пушкарь Е.Г. Исковое производство в советском гражданском процессе. Львов : Изд-во при Львовском ун-те, 1978. $191 \mathrm{c.}$

9. Устав гражданского судопроизводства 1864 г. / Проект новой редакции Устава гражданского судопроизводства. Санкт-Петербург : Сенатская типография, 1900. $1216 \mathrm{c.}$

10. Цивільний процесуальний закон радянського періоду ЦПК УРСР (текст і практичний коментарій). Київ : Юридичне видавництво, 1925. 339 с.

11. Гражданский процесуальний кодекс Украинской ССР. Киев : Госюриздат УССР, 1964. 178 с.

12. Зайцев И.Н. Судебное решение как процессуальный документ. Рос. юстиция. 1995. № 4. С. 20-21.

13. Штефан М.Й. Цивільний процес : підручник. Київ : Ін Юре, 1997. 358 с.

Information about authors: Perunova O. M.,

Candidate of Law, Associate Professor, Associate Professor at the Accounting, Taxation and International Economic Relations Kharkiv National Automobile and Highway University 25, Yaroslava Mudrogo str., Kharkiv, 61002, Ukraine

Leontieva L. V., Candidate of Law, Associate Professor, Associate Professor at the Accounting, Taxation and International Economic Relations Kharkiv National Automobile and Highway University 25, Yaroslava Mudrogo str., Kharkiv, 61002, Ukraine 